\title{
Utilization Of Nanogold And Nanosilver To Treat Herpes Disease: Case Study Of Herpes Transmission In Islamic Cottage Schools
}

\author{
Titik Taufikurohmah \\ Chemistry Department \\ Universitas Negeri Surabaya \\ Surabaya, Indonesia \\ titiktaufikurohmah@unesa.ac.id
}

\author{
Djodjok Soepardjo \\ Japanese Department \\ Universitas Negeri Surabaya \\ Surabaya, Indonesia \\ dsoepardjo@unesa.ac.id
}

\author{
Rusmini \\ Chemistry Department \\ Universitas Negeri Surabaya \\ Surabaya, Indonesia \\ rusmini@unesa.ac.id
}

\begin{abstract}
This research aims to utilize nanogold and nanosilver to treat herpes disease which suddenly appeared in one of the Islamic cottage schools. How this happened is not a study this time. Nanogold has an activity to increase cell proliferation and collagen biosynthesis. Nanogold also has an antioxidant activity. These activities are very necessary in the process of recovering tissue damage due to herpes virus attack, the herpes simplex virus (HSV). While nanosilver has an antimicrobial activity to a broad-spectrum antiviral including HSV herpes virus. Volunteers were Islamic cottage school residents (10 people) who have herpes and have been examined medically. The use of nanogold and nanosilver accompany medicines from doctors in general to reduce pain, fever and pain or heat felt by volunteers. The volunteer group on average recovered faster with fewer complaints than the control group (10 people) who only received doctor's medication. It can be concluded that nanogold and nanosilver accelerate the treatment of Herpes disease. Thus the impact of this research, nanogold and nanosilver are potential to be a future drug for herpes.
\end{abstract}

Keywords: nanogold, nanosilver, herpes disease

\section{INTRODUCTION}

This research aims to utilize nanogold and nanosilver to treat herpes disease which suddenly appeared in one of the boarding schools. How this happened is not a study this time. Seeing the condition of the inhabitants of the cottage where the skin on the back, neck, chest and stomach blisters. Red, bubbly and fluid-filled skin that can erupt and open. This exposed skin provides an opportunity for the virus to spread to other parts of the skin. Pain and heat are felt by patients and some even feel like burning. Nerves on the surface of the skin are also attacked by viruses so that the pain is increasingly unbearable. Herpes is included in the category of deadly diseases until 2010 [1]. The WHO even state that herpes as the top 10 causes of death [2]. The damage to the skin tissue due to herpes virus attack [3] is not much different from the effects of leprosy. The herpes virus must be immediately combated with antiviral including nanosilver [4]. Nanogold and nanosilver have been used for recovery of tissue damage due to leprosy. The question is whether the nanogold and nanosilver can also be used for this case of herpes?
Nanogold has an activity to of increase the cell proliferation and collagen biosynthesis [5]. Nanogold also has an antioxidant activity [6]. These activities are very necessary in the process of recovering tissue damage due to herpes virus attack, the herpes simplex virus (HSV). This virus not only attacks cells and skin tissue, but also attacks nerves [7]. Thus the need for the development of new skin and nerve tissue in healing this herpes disease [8] as well as antiviral treatment [9]. Conventional herpes drugs are generally only to reduce pain and reduce patient fever, namely from the paracetamol group. Basically a virus can never be paralyzed or made dead including the herpes virus [10]. The herpes virus will remain in the patient's body because herpes disease often recurs [11]. This relapse process is greatly triggered by a decreased immune condition. Nanogold increases glutathione activity, which is the immune system that each cell has [12]. With increased glutathione activity, cell-level immunity also increases and there is inhibition of viral proliferation [13]. Thus the body's immunity in general also increases [14]. The body is able to withstand the attack of the herpes virus when the immune system is strong [15]. This condition will weaken the herpes virus attack and the patient is said to have recovered. If this can be maintained the virus is silent and the patient does not recured [16].

In addition to activate glutathione, nanogolds are also active as antioxidants which help the body against the microbial and viral attacks [17]. Nanogolds also reduce free radicals that are formed during the process of tissue and cell damages. Mutable free radicals cause reduced the chain damage and reduced the patient pain [6]. Tissue repair gradually happens well. Wound healing also occurs so that the surface of the skin will be smooth and not red-red anymore [5]. Nanogold also has the activity to secrete $\mathrm{CN}$ - in fluid collected due to protein overhaul in tissue damage. The liquid in the skin bubbles will shrink and not break [18] [19].

Nanosilver has a broad spectrum of antimicrobial to antiviral activity including HIV-AIDs and HSV herpes virus [20]. Nanosilver works through the microbial cell wall, and disrupts metabolism from within the microbial cell nucleus [21]. Thus the microbial cell nucleus will rupture and be unable to control its life and not multiply again [22]. The antivirus mechanism of nanosilver has not been widely revealed, 
but it has paralyzed the attack of the HIV-AIDs virus. The same mechanism will be passed by the nanosilver to paralyze the herpes virus with the help of nanogold to build tissue damage [23] [24].

Volunteers are boarding school residents (10 people) who have herpes and have been examined by a doctor. They will get conventional treatment and be accompanied by the administration of nanogold and nanosilver drugs. The other 10 patients will get conventional treatment without treatment with nanogold and nanosilver. They are a control group. Basically, nanogold also has properties as a drug delivery. Conventional medicine will increase its efficacy because of the higher absorption of the drug in the presence of a nanogold drug delivery agent.

The use of nanogold and nanosilver accompany medicines from doctors in general to reduce pain, fever and pain or heat felt by volunteers. Nanogold and nanosilver have different activities that are both needed in the process of healing herpes. Theoretically it is fully supported, but is it also supported in this clinical trial? This question must be answered immediately in this research activity.

\section{RESEARCH METHODS}

The materials which were used in clinical trials is were nanogold and nanosilver in colloidal form with a concentration of $20 \mathrm{ppm}$. These materials were used to accompany the treatment of herpes, which the main functions is are drug delivery, antioxidant and antiviral. The volunteers are residents of one of the Islamic boarding school who have been declared herpes sick by doctors. 10 volunteers were treated using conventional herpes drugs and accompanied by nanogold and nanosilver as much as $600 \mathrm{ml}$ each week. The other 10 herpes patients only get conventional medication as prescribed by the doctor, so it is called the control group.

Research methods in the form of examinations on volunteers conducted once a week for 6 weeks, as well as recording medical records and taking pictures of their skin conditions. The analysis were done by comparing the initial conditions that are considered $100 \%$. Reduction in the area of skin damage and progress in health conditions in medical records is a measure of success in this study. The smaller percentage shows the recovery process that is reduced pain and blistered area of skin is also reduced.

\section{EXPERIMENTAL SETUP}

\section{A. Clinical Test Methods}

The clinical trial was conducted after there was an agreement between the volunteers and the researchers and the accompanying witnesses. Volunteers get an adequate explanation of their rights and obligations. Provision of conventional medicine and companion drugs in the form of nanogold and nanosilver is done once a week. The drug is taken 3 times a day with doctor's instructions. Likewise, nanogold and nanosilver were also consumed 3 times a day accompanying conventional medicine, except of the control group.

\section{B. Data Collection and Analysis Methods}

The data were in the form of initial medical records and their development during treatment. Medical records include the body temperature, heart rate, blood pressure, pain (burning and burning like heat) in the injured part and a picture of the area of the injured area. The pain compared to the beginning then the percentage is calculated. Likewise, the percentage of blisters and injured areas of the skin is calculated. The development of conditions from the beginning treatment, the first week, the second week and so on up to 6 weeks will be analyzed with a simple bar chart.

\section{RESULTS AND DisCUSSION}

The results of this clinical study have two data, they are medical record data of volunteers every week for 6 weeks and wound image data. The medical records of the volunteer and control groups were compared weekly using a simple diagram. The medical records referred to body temperature, heart rate, blood pressure, and pain. The initial medical record data up to the 6th week of the control group is listed in table 1 , while the volunteer group is listed in table 2. Furthermore, the data is compared between the control group and the volunteer group for each category of medical records. Image data that has been analyzed the percentage of wound area and its development every week can also be seen in table 1 for the control group and table 2 for the volunteer group.

TABLE I. AVERAGE DATA OF MEDICAL RECORDS AND IMAGE ANALYSIS OF CONTROL GROUPS.

\begin{tabular}{ccccccc}
\hline \multicolumn{1}{c}{ N } & Time & $\begin{array}{c}\text { Body } \\
\text { temper } \\
\text { ature( } \\
\text { C) }\end{array}$ & $\begin{array}{c}\text { Blood } \\
\text { pressure }\end{array}$ & $\begin{array}{c}\text { Heart } \\
\text { beat }\end{array}$ & $\begin{array}{c}\text { Main } \\
\text { pain } \\
\text { level }\end{array}$ & $\begin{array}{c}\text { \%o Area } \\
\text { of } \\
\text { Wound } \\
\text { Skin }\end{array}$ \\
\hline 1 & Start & 39 & $170 / 120$ & 94 & $100 \%$ & $100 \%$ \\
\hline 2 & Week-1 & 39 & $160 / 120$ & 92 & $90 \%$ & $92 \%$ \\
\hline 3 & Week-2 & 38,6 & $150 / 110$ & 88 & $80 \%$ & $88 \%$ \\
\hline 4 & Week-3 & 38,4 & $140 / 110$ & 86 & $80 \%$ & $76 \%$ \\
\hline 5 & Week-4 & 38,2 & $130 / 100$ & 85 & $70 \%$ & $55 \%$ \\
\hline 6 & Week-5 & 37,4 & $120 / 100$ & 84 & $60 \%$ & $48 \%$ \\
\hline 7 & Week-6 & 37,2 & $110 / 100$ & 82 & $50 \%$ & $40 \%$ \\
\hline
\end{tabular}

\section{A. Body Temperature}

The average body temperature of the 10 treatment groups and 10 control groups showed a decrease from fever to normal body temperature. Both the treatment group and the control group had different mean body temperature decreases. Although both groups are equally headed for normal body temperature, they occur at different times. The treatment group at the 4th week of average body temperature was normal while the control group of average body temperature became normal at the 5 th week. So the body temperature of the treatment group dropped faster and normal 
than the control group. This can be seen in Figure 1 The blue line is the control group and the yellow line is the treatment group. Nanosilver plays a role in reducing microbial activity so that inflammation is reduced more quickly characterized by faster body temperature going down to normal [20].

TABLE II. AVERAGE DATA OF MEDICAL RECORDS AND IMAGE ANALYSIS OF TREATMENT GROUPS

\begin{tabular}{|c|c|c|c|c|c|c|}
\hline \multirow{2}{*}{$\begin{array}{c}\text { N } \\
\text { o }\end{array}$} & Time & $\begin{array}{c}\text { Body } \\
\text { temper } \\
\text { ature( } \\
\text { C) }\end{array}$ & $\begin{array}{c}\text { Blood } \\
\text { pressure }\end{array}$ & $\begin{array}{c}\text { Hear } \\
\text { t } \\
\text { beat }\end{array}$ & $\begin{array}{c}\text { \% } \\
\text { pain } \\
\text { level }\end{array}$ & $\begin{array}{c}\text { \% Area } \\
\text { of } \\
\text { Wound } \\
\text { Skin }\end{array}$ \\
\hline 1 & Start & 39 & $172 / 122$ & 95 & $100 \%$ & $100 \%$ \\
\hline 2 & Week-1 & 38,2 & $160 / 120$ & 92 & $80 \%$ & $80 \%$ \\
\hline 3 & Week-2 & 37,6 & $140 / 110$ & 86 & $70 \%$ & $60 \%$ \\
\hline 4 & Week-3 & 37,2 & $130 / 110$ & 84 & $60 \%$ & $50 \%$ \\
\hline 5 & Week-4 & 37,2 & $120 / 110$ & 82 & $40 \%$ & $30 \%$ \\
\hline 6 & Week-5 & 37,0 & $110 / 100$ & 80 & $20 \%$ & $20 \%$ \\
\hline 7 & Week-6 & 37,0 & $110 / 100$ & 80 & $10 \%$ & $10 \%$ \\
\hline
\end{tabular}

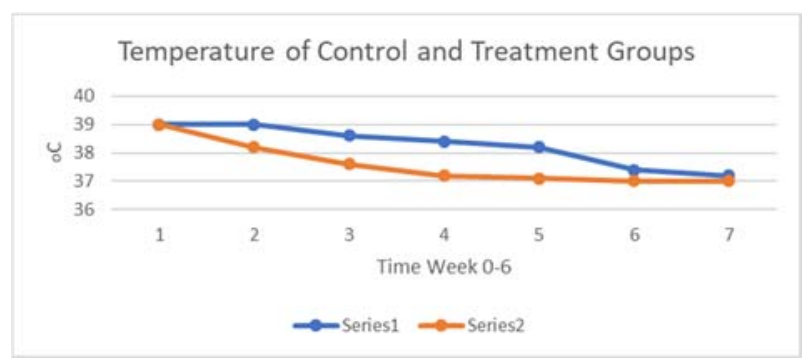

Fig. 1. Diagram of Decrease Body Temperature of Volunteer

\section{B. Blood Presure}

The average blood pressure of 10 treatment group and 10 control group experienced decreased from high blood pressure to normal blood pressure. Both the control treatment and the control group had different mean blood pressure drops. Although both groups are equally headed for normal blood pressure, they occur at different times. The treatment group at the 4th week of mean blood pressure was normal while the control group of mean blood pressure became normal at the 5 th week. So the blood pressure of the treatment group dropped faster and normal than the control group. This can be seen in Figure 2 the blue line is the control group and the yellow line is the treatment group. Blood pressure has a lot to do with the health of the heart organs, blood vessels and blood chemistry. Nanogold and nanosilver are very instrumental in the normalization of blood flow [18] [21].

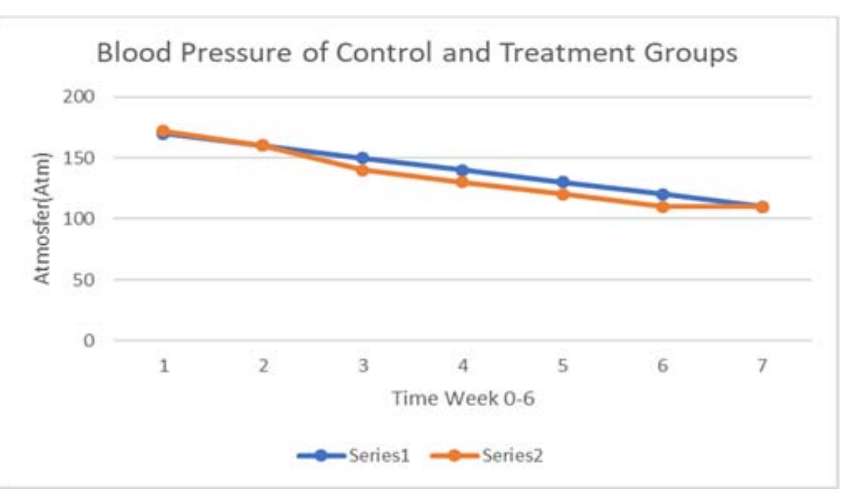

Fig. 2. Decrease of Blood Pressure of Volunteer

\section{Heart Beat}

The average heart beat per minute 10 people in the treatment group and 10 in the control group experienced a decrease from a high-speed heart beat to a normal heart beat. Both the treatment group and the control group had different rates of heart beat. Even though the two groups are heading for normal heart rates, they occur at different times. The treatment group at week 4 mean heart beat was normal while the control group at heart beat became normal at week 5. So the rate of heart beat of the treatment group dropped faster and was normal compared to the control group. This can be seen in Figure 3 The blue line is the control group and the yellow line is the treatment group. This is very related to the health condition of the heart muscles. Nanogold and nanosilver play a role in normalizing heart muscle health [21].

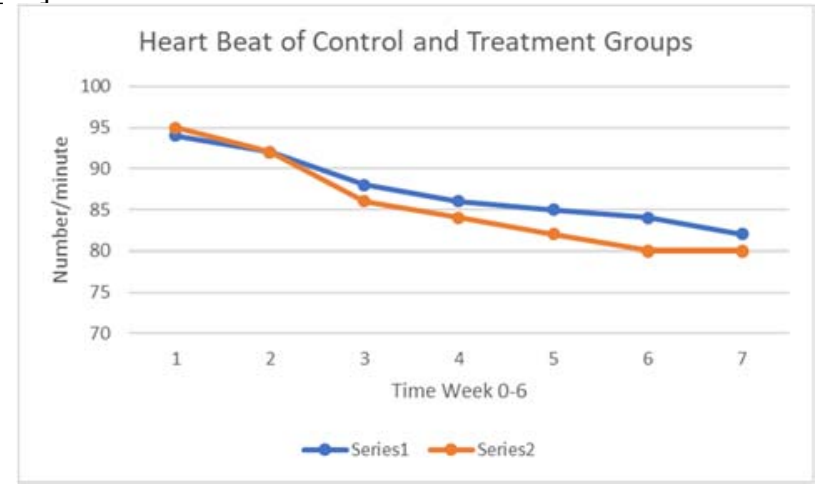

Fig. 3. Decrease of Heart Beat of Volunteer

\section{Percentage of Pain Level}

The average pain of 10 treatment groups and 10 control groups experienced decreased from initial pain $(100 \%)$ to the condition of pain that gradually dropped to normal or not painful. Both the treatment group and the control group had different rates of pain reduction. Even though the two groups are towards the recovery of pain or normal conditions, they occur at different times. The treatment group at the 5th week of the average pain has been normal while the control group of the average pain to be normal has not been reached until the 6th week of treatment. So the pain of the treatment group decreased faster and normal than the control group. This can be seen in Figure 4 The blue line is the control group and the yellow line is the treatment group. This is related to the health of peripheral 
nerves or taste nerves. Nanogold and nanosilver reduce pain, especially pain due to viral attacks on nerve cells [25].

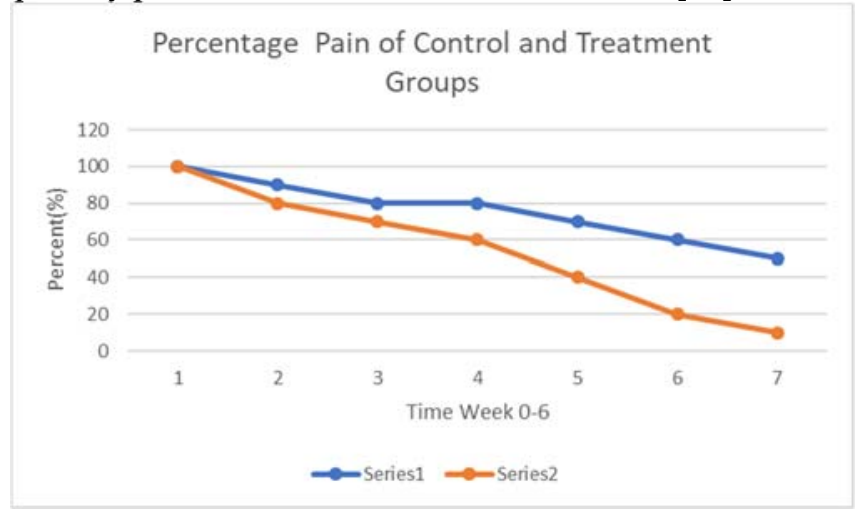

Fig. 4. Decrease Percentage Pain level of Volunteer

\section{E. Area of Wound Skin}

The average area of wound or blistered skin in 10 treatment groups and 10 control groups decreased from the initial wound area $(100 \%)$ to the condition of the wound being closed and recovering. Both the treatment group and the control group had an average reduction in the percentage of wound area are different. Although the two groups are heading towards wound recovery or normal conditions, they occur at different times. The treatment group at week 5 left an average of $20 \%$ and at week 6 it remained $10 \%$. The control group the percentage of the average area that still has open wounds in the 5th week is still $50 \%$ and the end of the 6 th week is still $40 \%$. So the percentage decrease in the area of the wound treatment group fell faster compared to the control group. This can be seen in Figure 5 the blue line is the control group and the yellow line is the treatment group. The treatment group recovered on average faster with fewer complaints than the control group (10 people) who only received doctor's medication. Nanogold plays a role in the formation of collagen fibers that help with wound closure. In addition, nanogolds also increase cell proliferation in the process of forming new tissues in the process of wound healing [5]. The detail healing process can see in Figure 6. that tell wound at upper Arm (treatment groups for 4 weeks). The other part on Figure 7. That wound healing process of herpes at upper chest (treatment groups for 4 weeks). The last that Figure 8. wound healing process of herpes at back of the neck (treatment groups for 4 weeks). The same healing process in view part of the body show that begin red color of skin and will be black skin in the last. This condition gov information that wound has been dry and healed.

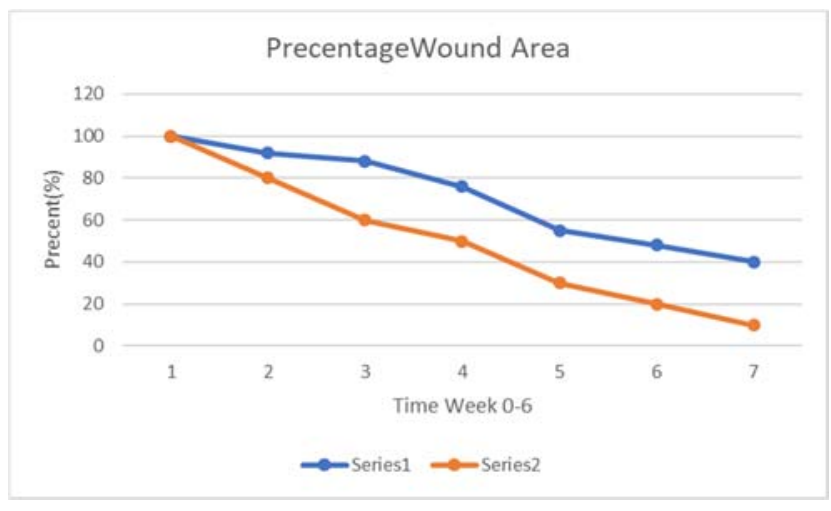

Fig. 5. Decrease Wound Area of Volunteer

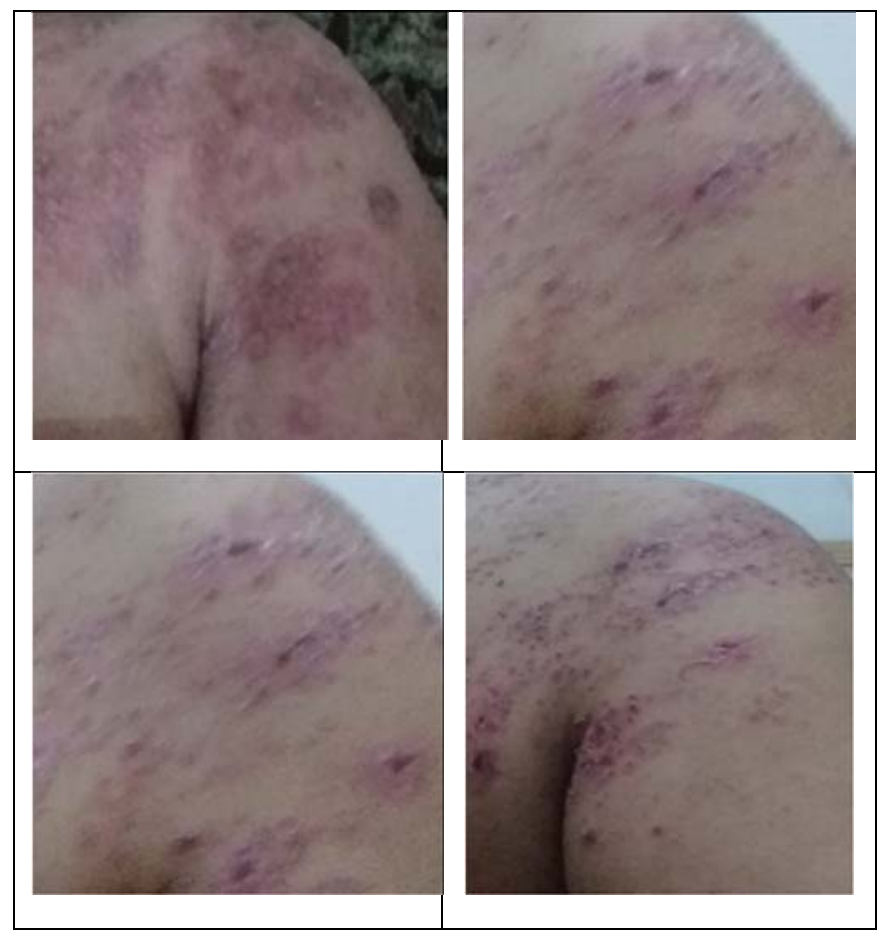

Fig. 6. Wound Healing Process of Herpes at Upper Arm (Treatment Groups for 4 Weeks) 


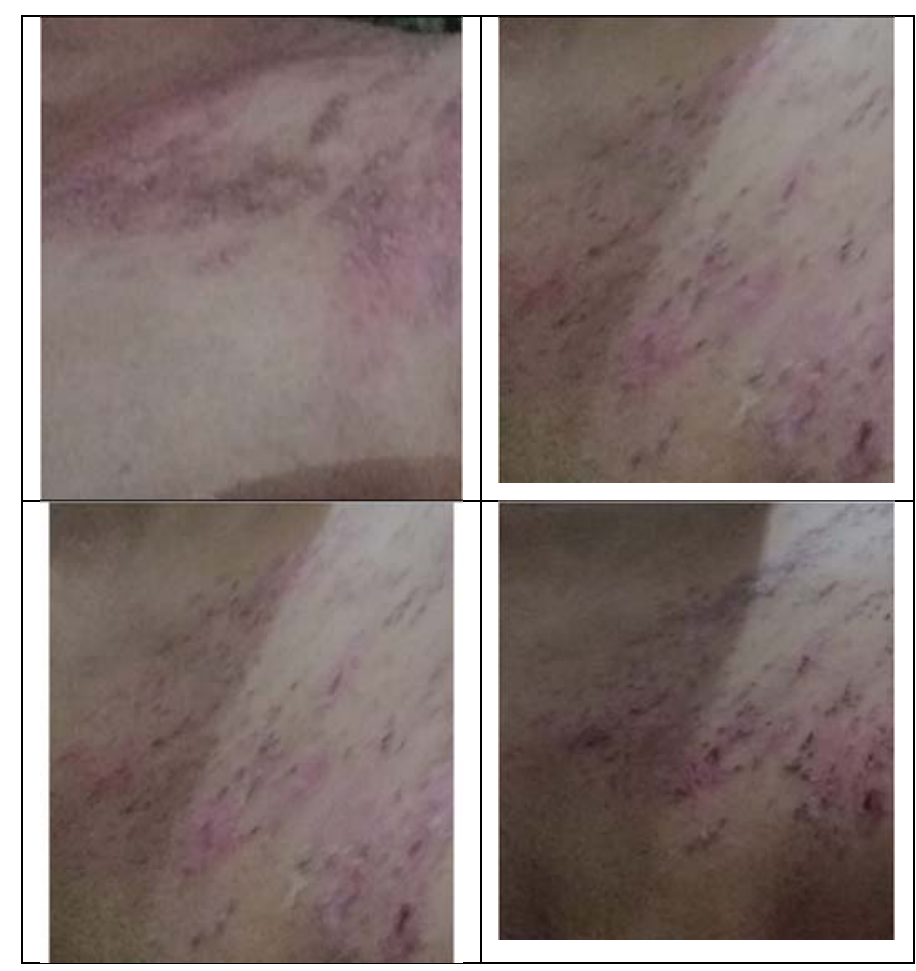

Fig. 7. Wound Healing Process of Herpes at upper chest (Treatment Groups for 4 Weeks)

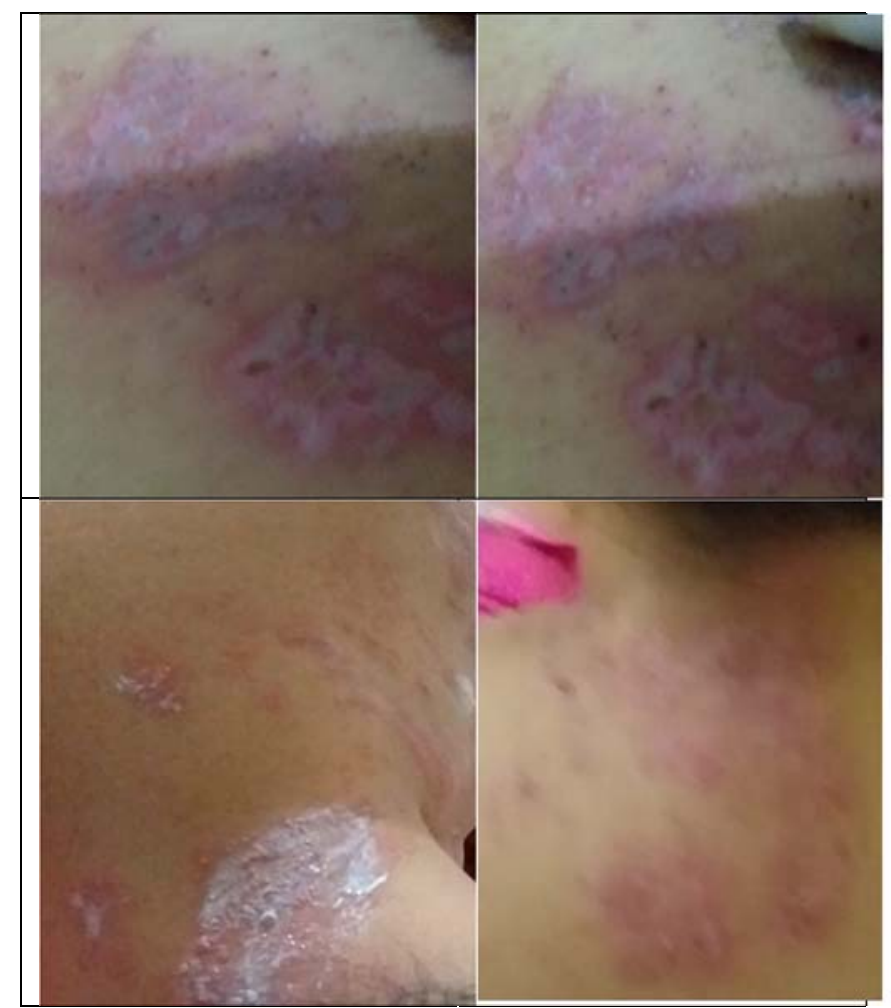

Fig. 8. Wound Healing Process of Herpes at back of the neck (Treatment Groups for 4 Weeks)

\section{CONCLUSION}

It can be concluded that nanogold and nanosilver accelerate the treatment of Herpes disease. Thus the impact of this research, nanogold and nanosilver has the potential to be a future drug for herpes. It is recommended to conduct clinical trials with a greater number of volunteers. This is needed to reinforce the effects of herpes treatment with nanogold and nanosilver. Currently nanogold and nanosilver as a companion to herpes drugs. Next nanogold and nanosilver as a drugs for herpes in the future.

\section{ACKNOWLEDGMENT}

Thank you to the Ministry of Research and Higher Education who have funded this activity included in the development research scheme in the 2019 fiscal year.

\section{REFERENCES}

1] Global and Regional mortality from 235 causes of death for 20 age groups in 1990 and 2010: a systematic analysis for the global Burden of Disease Study 2010. Lozano, R. et al. 1, London, England : Lancet, 2012, Vol. 380. 2095-2128.

[2]WHO. Top 10 causes of death. s.1.: WHO http://www.who.int/mediacentre/factsheets/ss310/en, 2017.

[3] trategies in the design of antiviral drugs. De Clercq, E. s.1. : Nat. Rev Drug Discov. PubMed CAS, 2002, Vol. 1. 13-25.

[4] Approved antiviral drugs over the past 50 years. De Clercq, $\mathbf{E}$ and $\mathbf{L i}$, G. s.1. : Clin. Microbiol. Rev, 2016, Vol. 29. 695-747.

[5] Mercury exposure effect to skin tissue of mus muscullus at fibroblasts cell proliferation and collagen quantity. Taufikurohmah, T, et al. 4, 2013, Res. J. Pharm. Biol. Chem. Sci, Vol. 4.

[6] Activity test of nanogold for reduction of free radicals, a pre-assessment utilization Nanogold in pharmaceutical as medicines and cosmetics. Taufikurohmah, T, et al. 2, 2012, Material science and engineering, Vol. 2, pp. 611-617.

[7] Auto-associative heparin nanoassemblies: a biomimetic platform against the heparin sulfate-dependent viruses HSV-1, HSV-2, HSV-16 and RSV. Lembo, D. et al. s.l. : Eur. J. Pharmaceutics Biopharmaceutics: Official Journal of Arbeitsgemeinschaft Fur Pharmazeutische Verfahrenstechnik e, 2014, Vol. 88. 275-282.

[8] Inhibition of Human metapneumovirus binding to heparan sulfate blocks infection in human lung cells and airway tissues. Klimyte, E.M, et al. s.1. : J. Virol, 2016, Vol. 90. 9237-9250.

[9] A haploid genetic screen identifies heparan sulfate proteoglycans supporting rift valley fever virus infection. Riblett, A.M. et al. s.l. : J. Virol, 2015, Vol. 90. 1414-1423.

[10] The AGMA1 poly(amidoamine) inhibits the infectivity of herpes simplex virus in cell lines, in human cervicovaginal histocultures, and in vaginally infected mice. Donalisio, M. et al. s.1. : Biomaterials, 2016, Vol. 85. 40-53

[11] The agmatine-containing poly(amidoamine) polymer AGMA1 binds cell surface heparan sulfates and prevents attachment of mucosal human papillomaviruses. Cagno, V.et al. s.l. : Antimicrob. Agents Chemother, 2015, Vol. 59. 5250-5259.

[12] Inhibition of HSV-1 attachment, entry, and cell-to-cell spread by functionalized multivalent gold nanoparticles. Baram-Pinto, D, et al. s.1. : Small, 2010, Vol. 6. 1044-1050.

[13] Polysulfonates derived from metal thiolate complexes as inhibitors of HIV-1 and various other enveloped viruses in vitro. . Bergstrom, D. E. et al. s.1. : Antivir. Chem. Chemother, 2002, Vol. 13. 185-195.

[14] Inhibition. Bowman, M. C. et al. 
[15]Candidate sulfonated and sulfated topical microbicides: comparison of antihuman immunodeficiency virus activities and mechanism of action. Scordi-Bello, I. A et al. s.1. : Antimicrob.Agrnts Chemother, 2005, Vol. 49. 3607-3615.

[16] The rise and fall of polyanionic inhibitors of the human immunodeficiency virus type 1. Pirrone, V, Wigdahl, B and Krebs, F.C. s.1. : Antivir. Res, 2011, Vol. 90. 168-182.

[17] Virucidal activity of a GT-rich oligonucleotide against herpes simplex virus mediated by glycoprotein B. Shogan, B, et al. s.1. : J.Virol, 2006, Vol. 80. 4740-4747.

[18] Synthesis, characterization and biological properties of Gold (III) compounds. Casini, A, et al. 2010.

[19] Human Skin penetration of Gold nanoparticles through intact and damaged skin . Filon, F.L, et al. February, 2011.

[20]Investigation of antibacterial properties silver nanoparticles prepared via green method. Shameli, K et al. 1, s.l. : Chemistry Central Journal, 2012, Vol. 6.

[21]Comparative in vivo assessment of some adverse bioeffects of equidimensional gold and silver nanoparticle and the attenuation of nanosilver's effect with a complex of innocuous bioprotectors. Katsnelson, B.A. et al. 2, s.1. : International Journal of Molecular Science, 2013, Vol. 14. pp.2449-2483.

[22]Potent antimicrobial agent and Its biosynthesis. Sarsar, V, Selwal, K.K. and Selwal, M.K. 4, s.1. : Nanosilver, 2014, Vol. 13. pp 546-554

[23] Nanosilver-Making difficult decisions. Podejmowanie, $\mathbf{N}$ and Decyzji, T. 2, s.1. : Obtaining nanomaterials, 2011, Vol. 18.

[24]Nanogold and nanosilver composites with lignin-containing cellulose fibres. Johnston, J.H and Nilsson, T. s.l. : Journal of materials Science, 2012.

[25] Biopharmaceutical Application of Nanogold. Alanazi, F.K, Radwan, A.A and Alsarra, I.A. 4, Saudi Arabia : Saudi Pharm. Journal, 2010, Vol. 18. 179-193.

[26] Detection of gold nanoparticles with different sizes using absorption and fluorescence based method. Zuber, A, et al. s.l. : Sensors Actuators B, 2016, Vol. 227. 117-127.

[27] Maximizing total phenolics, total flavonoids contens and antioxidan activity of Moringa oleifera leaf extract by the approprite extraction method. Vongsak, B, et al. 2012, JICP, Vol. 44, pp. 566-571.

[28] Amelioration of collagen induced arthritis in rats by nanogold. Tsai, C.Y, et al. 1, 2007, Arthritis Rheum, Vol. 56, pp. 544-554.

[29] The clinical test of Nanogold cosmetic for Recovering Skin Damage Due to Chemicals: Special case. Taufikurohmah, T, et al. 1, 2018, J Phys. Conf. Ser, Vol. 947.

[30] Histology Study: Pre-Clinic Test of Nanogold in mus muscullus skin, a fibroblast proliferation and collagen Biosynthesis. Taufikurohmah, T, et al. 2, 2013, Res. J. Pharm. Biol. Chem Sci., Vol. 3, pp. 55-61.

[31] Effect of fucoxanthin on lipopolysaccharide-induced inflammation in vitro and in vivo. Shiratori, K, et al. 2005, Exp. Eye. Res, Vol. 81, pp. 442-428.

[32] Antioxidant and antibiotic activities of some seaweeds (Egyptian Isolates). Shanab, S. 2, 2007, International Journal of Agriculture and Biology, Vol. 9, pp. 220-225.

[33] The retention time of inorganic mercury in the brain- A systemic review of the evidence. Rooney, J.P.K. 3, s.1. : Toxicol. Appl. Pharmacol, 2014 Vol. 274. 425-435.

[34] Gold Nanoparticles: Synthesis and Applications in Drug. Rashid, R, Murtaza, G and Zahra, A. July, 2014, Vol. 13. 1169-1177.

[35] Perturbation of pharmacologically relevant polyphenolic compounds in moringa Oleifera against photooxidative damages imposed by gamma radiation. Ramabulana, T, et al. 2016, JPPB Biology, Vol. 156, pp. 79 86.

[36] Inorganic mercury accumulation in brain following waterborne exposure elicits a deficit on the number of brain cells and impairs swimming behavior in fish. Pereira, P, et al. 2016, Vol. 170. 400-412.

[37] Antioxidant, antimicrobial and phytochemical variation in thirteen moringa oleifera Lam, Cultivars. Ndhlala, AR, et al. 7, 2014 Molecules, Vol. 19, pp. 10480-10494.

[38] Biosynthesis of metallic nanoparticles using plant derivates and their new avenues in pharmacological applications? An update report.
Kuppusamy, P, et al. doi: 10.1016/j.jsps.2014.11.013, 2016, Saudi Pharm Journal, Vol. 24, pp. 473-484.

[39] Collagen, elastic fiber, and extracellular matrix of dermis. Krieg, T, et al. 2012, Fitzpatrick's dermatology in general medicine In: Goldsmith, LA; Katz, SI; Gilchest, BA; Paller, AS; Leffell, DJ; Wolf, K, editors. ed. New York: McGraw-Hill companies, Vol. 8, pp. 1242-1285.

[40]The technique of enhancing the transdermal penetration for the gold nanoparticles and perspectives of application. Khayrullin, R.M, et al. July, 2013. 48-55.

[41] Antioxidant activity of enzimatic extracts from a bron seaweed Ecklonia cava by electron spin resonance spectrometry and comet assay. Jin Heo, Soo, et al. 2005, Eur Food Res Technol, Vol. 221, pp. 41-47.

[42] Sensors and actuators B: Chemical Eco-friendly colorimetric detection of mercury (II) ions using label-free anisotropic nanogolds in ascorbic acid solution. Jin, L and Han, C. s.1. : Sensors Actuators B. Chem, 2014, Vol. 195. 239-245.

[43] Reprogramming Cells for Brain Repair. Guarino, A.T and Mckinnon, R.D. 2013. 1215-1228

[44] Investigation of Mercury Content in Cosmetics Product by Using Direct Mercury Analyzer. Dahap, A.A. October, 2015.

[45] Mercury in skin lightening products. Cressey, P. s.1. : Health Risk Assessment, 2014, Vol. October.

[46] Mercury Toxicity and Contamination of Households from the Use of Skin Creams Adulterated with Mercurous Chloride (Calomel). Copan, L, et al. 2015. 10943-10954.

[47] Hyperintense lesions in brain MRI after exposure to mercuric chloridecontaining skin whitening cream. Benz, M.R, et al. 6, s.1. : Eur. J. Pediatr, 2011, Vol. 170. 747-750

[48] Gold nanoparticles: Opportunities and challenges in nanomedicine gold nanoparticles. Arvizo, R, Bhattacharya, R and Mukherjee, P. June, 2010.

[49] In Vivo skin irritation potential of acream containing Moringa oleifera leaf extract. Ali, A, et al. 6, 2013, AJPP, Vol. 7, pp. 289-293.

[50] Use, production and availability product, packaging and ingredients health effect and how to measure exposure. Africa, S, Kong, H and Republic, D. 2004 
